Irene Salvo

\title{
Experiencing curses: neurobehavioral traits of ritual and spatiality in the Roman Empire
}

\begin{abstract}
Love, wish for revenge, fear, hope: ancient cursing rituals managed to embrace a vast spectrum of emotions. They were prompted by emotional experiences, they manipulated feelings, and their result could have been a renewed emotional state. This paper intends to look at how the archaeological and ritual settings contributed to shape the emotional and bodily experience of individual participants. Active compounds such as frankincense could have helped the uplifting of negative emotions, but lead exposure could have provoked health damage. Sensory deprivation could have enhanced the sense of being in contact with the divine or could have distorted perception. The case studies include a selection of documents from the sanctuary of Demeter and Kore in Corinth (I-II CE), the sanctuary of Isis and Magna Mater in Mainz (I-II CE), and that of Anna Perenna in Rome (II-V CE). From these texts and their contexts, it is possible to attempt a sketch of the cognitive and embodied aspects of cursing rituals as a multi-sensory experience.
\end{abstract}

\section{Introduction}

The historian who intends to illuminate the history of emotion in antiquity could hardly avoid to look at the epigraphical evidence. Among the various typologies of inscription, curses offer a base for studying the description and

\footnotetext{
Acknowledgement: I would like to thank the editors for their invitation to Eisenach for the opportunity to reflect on this topic and the days of constructive discussions. I would like to thank also Therese Fuhrer for inviting me to the University of Munich, where I presented a version of this paper receiving useful feedback, and Angelos Chaniotis for his comments on my oral presentation. Yulia Ustinova kindly read and commented on a draft of this chapter, helping me to fine-tune my argument. I am also grateful to Esther Eidinow for her fruitful suggestions. I would like to warmly thank Laura Baroncelli for discussing with me the research in neurobiology here cited. Any error remains mine. This research has been generously funded by the Deutsche Forschungsgemeinschaft (DFG) at the University of Gottingen, Collaborative Research Centre 1136 Bildung und Religion, sub-project C01 'Aufgeklärte Männer - abergläubische Frauen? Religion, Bildung und Geschlechterstereotypen im klassischen Athen'.
} 
display of emotions as well as for understanding mechanisms for arousing emotion. In this sense, curses are both emotional and emotive. They are a byproduct of an emotional state, sometimes they try to describe it, while they may aim to arouse an emotion in a human or a divine addressee. ${ }^{1}$ Furthermore, curse tablets are not just texts: they are part of a set of components of a cursing rite. It is in their ritual dimension that they acquire another emotive connotation: they can transform the emotions of the participants of the rite. ${ }^{2}$ In this respect, they can testify to the religious experience of individuals. About sixteen hundred tablets attesting cursing practices are scattered in the Mediterranean region and beyond, dating from the 6th century BCE to the 7th century CE.

Notwithstanding this considerably large number of documents, ${ }^{3}$ their fragmentary status as well as the few details that we can collect on the exact circumstances of their deposition render ambitious the intent of reconstructing the religious experience of curses. However, the challenge is worth the effort, since it may contribute to demonstrating how mind and body reacted to the ritual context. This chapter aims to unpack the experience of cursing rituals, looking at the way in which the spatial features of the place of deposition shaped the emotional and bodily effects of participating in the ritual.

Experience is here intended as the process of being the protagonist of an event that has an impact on feelings and existence. This process results from the interaction of the human mind and body with the environment. It is to investigate how the perception of ritual actions could be grounded within the physical world and its characteristics, and whether objects and procedures determined what was internally and corporeally experienced. In brief, this chapter will highlight instances in which cursing rituals could have been inscribed upon bodies and mental states. To trace the experiential dimension of religious actions and moments, contemporary studies in the field of neuroscience can help improve our understanding of what could have happened during the

1 On the strategies for persuading mortals (targets of a curse) and immortals (addressees as mediators of a curse), see Salvo 2016, with previous bibliography.

2 Focusing on the feeling of victimization and wish for revenge, in Salvo 2012 I have argued that cursing rituals helped to channel negative emotions aroused by a suffered injustice and to contain the escalation of violent behavior. Cf. Eidinow 2016, 221-223, on how curses generated and exacerbated anxiety, gossip, and cursing within a community.

3 Gager 1992, 3 counted an excess of fifteen hundred. The online database Thesaurus Defixionum Magdeburgensis (TheDeMa, http://www-e.uni-magdeburg.de/defigo/thedema.php, last accessed 20.03.2018) currently includes 1288 entries, and is constantly updated by the research group "Magische Verfluchungen als Durchsetzung von Recht. Transkulturelle Entwicklung und individuelle Prägung der antiken Fluchtafeln,“ based at the Otto-vonGuericke-Universität Magdeburg and directed by Martin Dreher. 
deposition of a curse tablet. Finally, the concept of spatiality serves to underline in which ways the physiology of the human mind, elements of culture, and the spatial setting cooperated to affect religious thought.

It must be specified that not every single curse tablet can offer sufficient elements for a similar historical analysis. A deeper understanding of the experiential aspects of curses can be possible especially in the case of tablets deposited in sanctuaries and excavated in archeological digs. The analysis in this chapter will be focused on three sites that were particularly generous in restituting curse tablets from a secure archeological context: Corinth, Mainz, and Rome. The epigraphical findings are dated from the 1st to the 5th century CE. We will examine the Greek documents first and then the Latin evidence, starting therefore with Corinth.

\section{Feeling the curse at the sanctuary of Demeter and Kore in Corinth}

On the Acrocorinth, in the second half of the 1st century CE, the Sanctuary of Demeter and Kore was starting to regain life after a long period of abandonment since the sacking of the city in $146 \mathrm{BCE} .{ }^{4}$ The systematic excavation campaigns of the American School of Classical Studies at Athens have restituted a considerable amount of data on the life of the site across the centuries, and have offered a precious contribution to the history of ancient magic, since seventeen Greek inscriptions on lead tablets, plus one in Latin, have been found. These texts not only expand an ever-growing corpus of magical spells, but also present the opportunity to analyze the spatial backdrop of the cursing rite. The deposition of the tablets probably took place even before the architectural renovation works were accomplished during the second half of the 1st century $\mathrm{CE}$, since the tablets are the most ancient findings in the sanctuarial area after the establishment of the new city with Roman colonists in 44 BCE (Stroud 2013, 153). The earliest tablets are two identical texts probably written by the same hand:

Maxima Pontia, for destruction. ${ }^{5}$

Maxima Pontia, for destruction. ${ }^{6}$

4 On the history and phases of the sanctuarial buildings, see Bookidis and Stroud 1997.

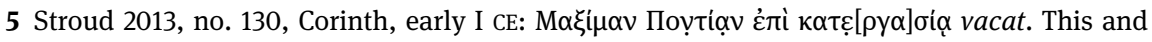
the following Corinth texts and translations are from Stroud 2013, in some instances slightly modified.

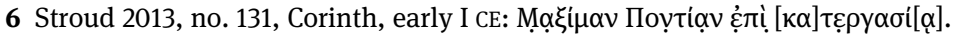


These two very brief texts tell us very little about the circumstances of the ritual, why the target victim was cursed, and who was the author or commissioner. However, their archeological context offers additional clues. They were found together, unrolled, though folding lines are visible, in the filling of a reused dining room of the Classical and Hellenistic period and near two thymiateria (Bookidis and Stroud 1997, 274-276; Stroud 2013, 138-139). In the Roman period, the dining benches were covered with layers of earth, and the space was re-functionalized for magical purposes. ${ }^{7}$ The incense burners bear signs of prolonged use (Stroud 2013, 139). This might constitute an example of the deposition of cursing tablets within a space sacred to Demeter and Kore, although still in an initial phase of renovation and reappropriation, and in an environment filled with the fumes of frankincense. The visual and olfactory stimuli triggered by frankincense would have probably enhanced the setting apart from the ritual moment and its efficacy. The offering of frankincense, burnt before uttering a prayer or over an inscribed tablet, often recurs in the prescriptions of the Greek Magical Papyri. ${ }^{8}$ The fumes from the burning of incense increase the sense of uplifting in human perception, as is now proven by experiments in the field of psychopharmacology that have traced the effects of the resin of the Boswellia, the tree from which frankincense is produced. In the mouse brain, frankincense shows anxiolytic and antidepressive effects comparable to those obtained using drugs as potent as diazepam and desipramine (Moussaieff et al. 2008). Although “destruction for Maxima Pontia” appears as a tense and enraged request, which needed to be solicited twice, the ritual agent was at the same time immerging him- or herself in calming suffumigations of incense.

Further data on the environment of a cursing ritual come from another findspot in the Lower Terrace of the sanctuary, that is from Room 7 of the Building of the Tablets, as identified by the excavators (Bookidis and Stroud 1997, 277-291; Stroud 2013, 138-153). Ten tablets were found possibly near their original place of deposition, around four small stone supports for altars or

7 The excavators do not rule out the possibility that the filling could be debris, but the uniform leveling and the upright position of one of the thymateria suggest to them a conscious reuse of the space, see Bookidis and Stroud 1997, 276; Stroud 2013, 139.

8 A selection of examples: offerings of frankincense in a spell producing dreams: PGM IV.3195

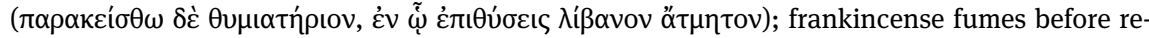

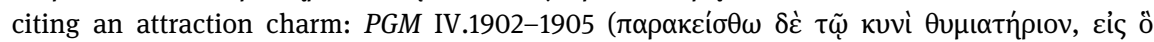

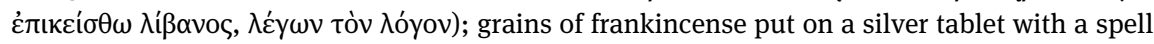

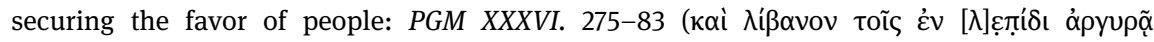
$\chi \alpha \rho \alpha \kappa \tau \tilde{\eta} \rho \sigma \iota)$; a spell that accomplishes everything instructs to inscribe a censer: $P G M$ IV.

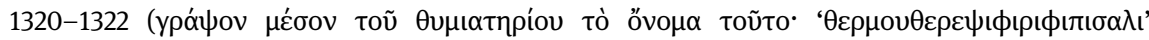

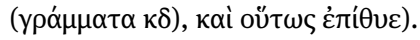


tables or thymiateria. ${ }^{9}$ Three tablets, in particular, allow us to reflect upon the ritual setting. On a rolled up tablet inscribed on both sides, the only one with intelligible words, we find this text:

I bind down Secunda Postumia before Herakleides and before all men, her mind, her wits, her hands, her sinews, her knees, her entire body. I bind down Postumia Secunda before all [men/persons]. ${ }^{10}$

Jealousy was an emotion that frequently prompted the dedication of a curse. In this case, the attack is against a certain Postumia Secunda. Her name is repeated twice in a chiastic position, ${ }^{11}$ and she probably aroused the jealousy of the writer or commissioner of this tablet. It is not straightforward to identify the gender of the sender of this message. As Stroud notes, it may be a man who wants to prevent the union of Postumia Secunda with other men, or it may more probably be a woman who was in love with Herakleides and who intended to protect her man from being seduced by Postumia Secunda (Stroud 2013, 89). Stroud is inclined towards this second possibility, since the text lacks other features of erotic attraction curses, such as the invocation of a divine helper who drags the beloved person to the defigens and the request that the victim forgets food, sleep, and family (Stroud 2013, 89). Indeed, it makes perfect sense to imagine a woman as the author or commissioner of this tablet. However, it could also be a case of same-sex attraction: a man who intended to keep Postumia Secunda away from his Herakleides or a woman who wanted to guarantee her exclusive possession of Postumia's body. Thus, the identification of the gender of the defigens remains uncertain. Additionally, it cannot be ruled out with confidence that the text functioned in spheres other than love magic. We only know that the cognitive faculties and then the bodily organs of a woman are cursed. The scope of this could also have pertained to a competition in commercial or agonistic domains, or perhaps Postumia Secunda had wronged somehow the author/commissioner of the

9 Stroud 2013, nos. 118-127. See Bookidis and Stroud 1997, 282: "It is our opinion that they were found near where they had been placed. Their appearance in consecutive strata suggests this." They have also found small pieces of lead around base B.

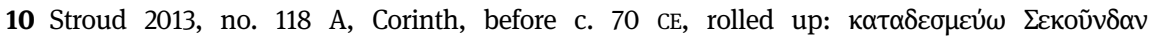

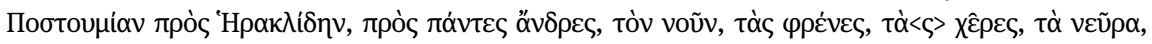

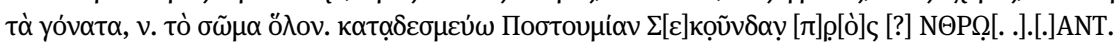

11 See Stroud 2013, 89 on lines 2-4: "Postumia Secunda, written in this order here, but in proper sequence, Secunda Postumia, in lines 12-14. Possibly the reversal was thought to have some magical force, or, as B. Millis suggests to me, it might indicate how she was normally addressed. The name is apparently unattested so far in Corinth." 
tablet, prompting a cursing prayer. ${ }^{12}$ Similarly formulaic texts had typically an undefined motivation, as this example from Athens shows:

I bind Protophanes (?) down - him and his hands and feet \{and feet and tongue and mind before Hermes Eriounios and before Hekate Epitymbia (?). I bind Hedea and Phaidimos down. I bind him down and his feet and hands and tongue before Hermes Eriounios and before Hekate and Hermes. I bind Hedea down and always ( . . . $)^{13}$

In this curse, more than one person is attacked, and the names of the gods that should help are invoked. The epithets in association with Hermes and Hekate pertain to the sphere of supplication (if we imagine Épıyoúvıov as connected to the grasping of knees) and of the Underworld. ${ }^{14}$ Supplicatory tones to Chthonian divinities recur in another tablet from the Corinthian Sanctuary:

Text A: Lord gods of the underworld ---

Text B: Lord, expose them and - cut their hearts, Lord, by means of the gods of the underworld. THE[--- $]^{15}$

With the invocation to the kúpıo $\theta \varepsilon o i$ (master gods), a hierarchical relationship is here construed with the divine interlocutors, who are declared sovereign, powerful, and authoritarian, while the worshipper assumes a position of inferiority and subjugation. ${ }^{16}$ This cursing prayer testifies to a perceived suffered injustice, something that was inflicted by those who are now the target victims (Versnel 2010, 314 with previous bibliography). The dedicator seeks to have the truth revealed about the people who committed a wrong against him or her. The punishment indicated in Text B consists on one side of being found out and going through a public

12 On 'anatomical' curses see Versnel 1998: he distinguishes between curses in which the listing of body parts aims at restraining the abilities of an opponent (e.g. the feet of a race runner), and those in which it aims at provoking intense sufferings in the target victim as a measure of revenge for injustice or love conquest.

13 SEG XL 266, Athens, second half of the IV BCE, folded and nailed: $\alpha \alpha \tau \alpha \delta[\tilde{\omega}]$ ПPOQФ़NATHN

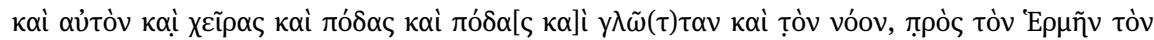



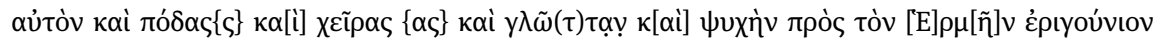

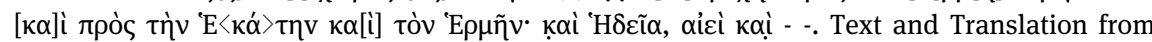
Curbera 2016.

14 See Curbera 2016, 112 for a deeper analysis of the two epithets.

15 Stroud 2013, no. 127, Corinth, Roman period, unrolled but folding lines distinguishable:

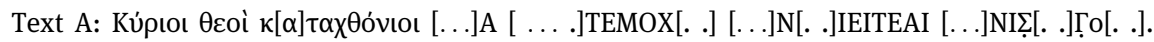

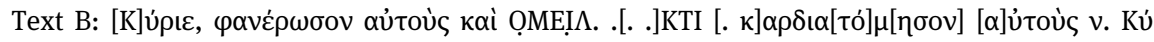

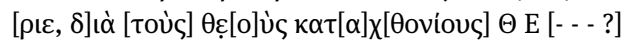

16 On the кúpıo $\theta \varepsilon o i$, cf. Nicole Belayche in this volume. On the construction of a hierarchical relationship of gods/mortals, see Versnel 2002; Chaniotis 2009; Salvo 2012, 258. 
disclosure of probably socially embarrassing actions, ${ }^{17}$ and on the other side in having the hearts cut. ${ }^{18}$

Avenging gods, but this time without their placement in a superior rank, are explicitly invoked in another tablet from Corinth:

For her destruction and evil-eye bewitchment I deposit (this?) with you avenging gods and avenging goddesses so that you may [make] Karpime Babbia, weaver of garlands, phi[---] ${ }^{19}$

According to the first editor, the hand of this tablet seems to have inscribed two other curses: one is certainly addressed against the same person, Karpime Babbia, while in the other the name is not mentioned, but given the similarities in the handwriting he suggests that all three tablets had the same author and target (Stroud 2013, 101; the three curses are Stroud 2013, nos. 123, 124, 125/126). The translation above is slightly modified from Stroud, who translates is

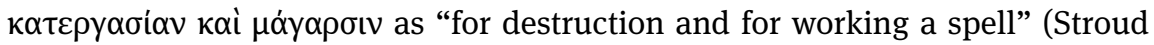
2013, 102). To better explain the reasons why this translation needs nuancing, it is worth quoting his comments on the term $\mu \alpha \dot{\alpha} \alpha \rho \sigma ı v$ : "Following a suggestion of Jordan, I have interpreted МАГАР $\mathrm{IN}$ as the accusative singular of the noun, $\mu \alpha \dot{\gamma} \alpha \rho \sigma \iota \varsigma$, attested apparently only in Hesychios (s.v.), which could be derived from the verb $\mu \varepsilon \gamma \alpha i \rho \omega$, one of whose meanings is equivalent to $\beta \alpha \sigma \kappa \alpha \dot{v} \omega$ (be-

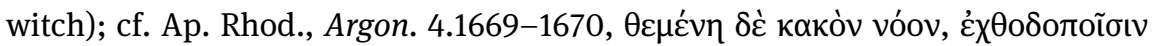

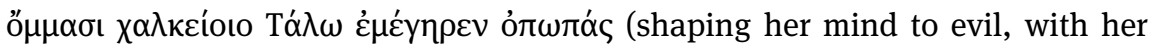
hostile glance, she bewitched the eyes of Talos, man of bronze)" (Stroud 2013, 103). This interpretation is compelling, but it is important to fine-tune it and to highlight the value of this text as a precious addition to our understanding of ancient mentalities and magical belief.

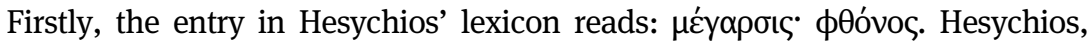
then, clearly states the connection between $\mu$ ćyopoıs and the emotion of envy, in the sense of envious feelings that can cause misfortune to the envied person.

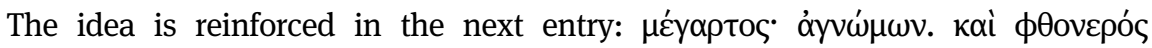

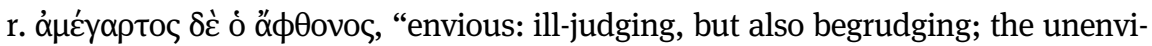
able is not provoking envy," or, in other words, the one who is miserable is free

17 On humiliation, cf. Eidinow 2016, 225-232.

18 See Stroud 2013, 117 on parallels for cutting the heart of a victim of a magical attack. Although another expression is used, in a Coptic prayer for justice against two women and a man, the seven archangels (Michael, Gabriel, Raphael, Rakuel, and Suriel in particular) are asked to strike them with their swords, see Meyer and Smith 1999², no. 91, 92.

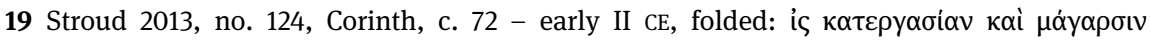

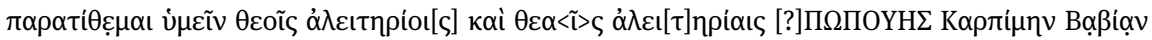

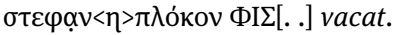




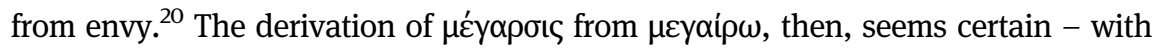

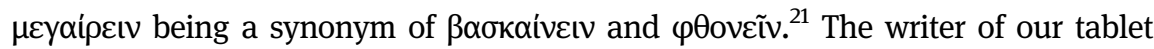
possibly misspelled the word $\mu \varepsilon^{\prime} \gamma \alpha \rho \sigma v v$ as $\mu \alpha \dot{y} \alpha \rho \sigma t v$, and, very likely, the intention was to cast the Evil Eye on Karpime Babbia. ${ }^{22}$ The interplay between curses, prayers, envy, and the Evil Eye is a not uncommon feature of the involvement of immortals in social relationships. ${ }^{23}$ In this Corinthian tablet, it creates an aggressive effect. The avenging gods must destroy the target and inflict upon her the worst misfortunes provoked by the power of the Evil Eye. The picture becomes more evident when the tablet no. 124 is read together with the other curses against the same target, nos. 123 and 125/126. While in the text no. 123 the destruction of the

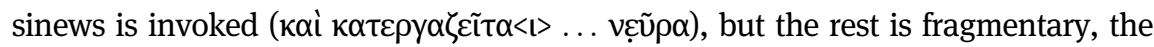
curse inscribed in the two tablets 125 and 126, fastened together by a nail, preserves the longest text found in the sanctuary. From this document, it seems to emerge that the author of these three curses was a woman who envied the fertility of Karpime Babbia and hoped to gain a more successful fecundity for herself; moreover, she had perhaps experienced mocking in public by Karpime Babbia

20 Cf. Homer, Odyssey, 17.219: ஷ́ $\mu \dot{\gamma} \gamma \alpha \rho \tau \varepsilon \sigma u \beta \tilde{\omega} \tau \alpha$, wretched swineherd! (LSJ).

21 A Salaminian word according to the Scholia Vetera to the Iliad: Scholia ad Ilias 13.563:

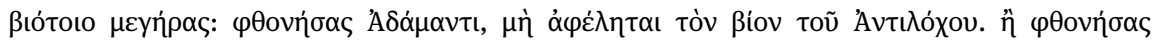

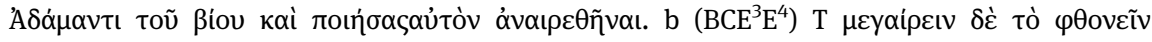

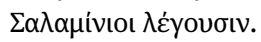

22 In TheDeMa no. 357 (http://www.thedema.ovgu.de/thedema.php?tafel=357\&seite=1, last accessed 30.09.2017), Sara Chiarini offers a German translation of this tablet: „Zum Niederwerfen und Missgunst übergebe ich euch, schadenfrohen Göttern und schadenfrohen Göttinnen, ... Karpime Babia, die Kranzflechterin, an ... "She also notes that Stroud's translation is misleading, and adds in the commentary: „Zu $\mu \alpha \dot{\alpha} y \alpha \rho \sigma \varsigma$ vgl. Hesych. $\mu \varepsilon \dot{y} \alpha \rho \sigma \iota \varsigma \cdot \varphi \theta$ óvo

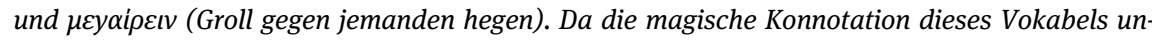
sicher ist, halte ich für vorsichtiger, die primäre und allgemeinere Deutung von ,Missgunst 'anzunehmen." A glimpse into a third language, other than English and ancient Greek, may help indeed to deeper understand how envious emotions function on several layers, since German distinguishes between Neid, Missgunst, and Scheelsucht. According to Georg Simmel, Missgunst is the envious desire of an object, not because it is desirable per se, but only because another subject has it. One is ready to destroy that object so as to impede the other person from having it (Simmel 1992, 319). In Eberhard 1910, 262-263, Neid is translated as "envy," while Missgunst is "grudge," since it comes into play when the person who is enjoying a privilege is not deemed worthy of it by the begrudging subject. Finally, Scheelsucht is the highest grade of envy and the more loaded with hate, and is translated as "mean jealousy, malocchio." In my interpretation, $\mu \varepsilon ́ \gamma \alpha \rho \sigma \iota \varsigma$ would find a better equivalent in this last term.

23 It was rooted in ancient Greek mentality and was subsequently incorporated in the Greek Orthodox Church, where prayers and rituals to unbewitch someone (xematiasma) are still practiced, see Stewart 2008, 90-93 among others. Cf. NGCT 24, side A, Attica, early IV BCE, with Eidinow 2016 on $\phi \theta$ óvos, envy, and ancient Greek curses. 
because of her sterility. ${ }^{24}$ Each one of these curses reinforces the others, and each time new divine powers are called upon. ${ }^{25}$ The reason behind depositing more than one tablet was plausibly an intent to activate a greater number of different supernatural agents, asking them to accomplish several kinds of punishments, whose common denominator was the psychological and physical devastation of Karpime Babbia.

The curses against Karpime Babbia were all found in the Building of the Tablets, a small and dark room where cursing rituals were probably performed at night: alongside the lead tablets and the thymiateria, an abundant quantity of fragments of lamps as well as of pouring vessels was excavated (Bookidis and Stroud 1997, 277-291; Stroud 2013, 138-153). Stroud has highlighted the characteristics of this site: "a setting of chanting spells; pungent, smoky incense; manipulation of lamps; possibly sipping of potions; and probably other rites in addition to the folding, spiking, and depositing of the tablets themselves around or on four stone bases" (Stroud 2013, 115). A few questions arise from these observations. Did such a ritual setting affect the experience of depositing the curses? Moreover, who were the individuals operating in Room 7 ? It was a ground-floor room of c. $25 \mathrm{~m}^{2}{ }^{26}$ Stroud notes that, given the small dimensions of the space, "only a few people at a time" participated in the rituals: there are no data from which to infer that they were performed secretly, nor it is possible to tell whether in groups or alone, by the persons concerned or religious personnel only (Stroud 2013, 142). Furthermore, it is hard to identify who inscribed a curse tablet, whether the attacker or a professional scribe, and it can be tentatively determined only from case to case. ${ }^{27}$ However, it is not implausible to imagine that, although the spell-casters might not have inscribed the tablets autonomously, they could have been present at the deposition ceremony attending it as protagonists.

24 For an analysis of Stroud 2013, nos. 125/126, see Stroud's commentary ad hoc, Versnel 2010, 314, and Salvo 2017, where I argue that this text is a combination of a curse and a fertility ritual.

25 In favor of a varied group of supernatural entities, I would rule out the possibility envisaged by Stroud 2013, 103 that the avenging gods and goddesses invoked in no. 124 could be identified with the divinities named in no. 125/126, that is, the Moirai Praxidikai, Hermes Chthonios, Ge, and the children of Ge. In Stroud 2013, no. 123, line 5, there are traces of the name of a katachthonian deity, see Stroud 2013, 101.

26 It is $5.08 \mathrm{~m}$ wide and $5.35 \mathrm{~m}$ long: Bookidis and Stroud 1997, 277; Stroud 2013, 142.

27 Cf. Tomlin 1988, 100 on the tablets found in the temple of Sulis Minerva at Bath (UK) and inscribed by "a mixture of professionals and amateur scribes." Cf. also Dufault 2017 on the limited evidence for professional scribes. 
We can try to imagine and visualize the interactions inside this room. Archaeologists have shown how the configuration of space can shape the emotions of the people using a building. The architectural and decorative arrangements of temples could have marked the entrance of an out-of-the-ordinary place, and facilitated a pious disposition of the worshipper towards the divine. ${ }^{28}$ In the case of the Sanctuary of Demeter and Kore in Corinth, the design of the Building of the Tablets could have had a significant influence on the emotive state of the people who performed rituals inside it. An individual was receiving a variety of stimuli, and each sense was engaged: eyes had to get used to darkness, ${ }^{29}$ ears were hearing chanting spells and murmured prayers, taste was perhaps challenged by unusual ingredients of magical potions, the olfactory system was sending to the brain relaxing messages from the incense, hands were touching cold, dusky-colored, and menacing lead tablets. The reception of one stimulus might have created the conditions for perceiving (with or without awareness) the subsequent ones as connected cues, even if unrelated, activating priming mechanisms. ${ }^{30}$ Religious priming might have boosted prosocial behavior, ${ }^{31}$ as in the case of the frankincense that generated calming effects, causing a transformation in the emotive state of the ritual agents and helping them to abandon negative and aggressive feelings in favor of a sense of calm derived from having accomplished the necessary steps. However, participating in the cursing ceremony might also have been a dangerous experience, as we will see in the next case study.

\section{Ritual experience and neurobehavioral toxicity of lead at the sanctuary of Isis and Magna Mater in Mainz}

In 1999 construction works in the center of Mainz revealed the remains of a joint temple dedicated to Isis Panthea and Magna Mater, which was active in the years between 70 and $130 \mathrm{CE}$. Among tons of the remains of burnt offerings in sacrificial

28 Metzler 1995; Marconi 2007. On the investigation of past emotion from archaeological sources, see, among others, Tarlow 2012; Masséglia 2012; Hamilakis 2013.

29 On magic performed in secluded and dark places, see Ustinova 2009, 240-244.

30 To condense very essentially what priming is. On priming and related debates, see recently Molden 2014.

31 On religious priming and prosociality (behavior that benefits others), see Shariff et al. 2016. I owe this reference to Yulia Ustinova. 
pits and delimitated areas, 34 Latin curse tablets were found. ${ }^{32}$ Of these, 14 texts preserve intelligible and longer texts, mostly concerning thefts or frauds. The examples here selected are particularly revealing on the neurobehavioral aspects of ritual. In the following text, a crafted poetic simile conceals a powerful spell:

(Whatever) Aemilia Prima, (the lover?) of Narcissus may do, whatever she attempts, whatever she does, let it all turn into its opposite. May she get up (out of bed) out of her mind, may she go about her work out of her mind. Whatever she strives after, may her striving in all things be reversed. May this befall Prima, the lover of Narcissus: just as this letter never shall bloom, so she shall never bloom in any way. ${ }^{33}$

For the present purpose, two points are worth highlighting. Firstly, we find an uncommon adjective like amentitus used with the intention to provoke in the victim a state of insanity and madness, similarly obtained by curses explicitly targeting cognitive faculties. ${ }^{34}$ It has been convincingly suggested that this tablet aimed at making Prima Aemilia infertile (Sánchez Natalías 2018, 12). Reproductive impairment fits well in the picture intensifying the desired psychological distress. Secondly, the simile of blooming flowers, perhaps inspired by the name of Prima Aemilia's lover, Narcissus, shows a certain degree of poetic and personal choice. Although it follows the formulaic motif of sympathetic magic and the similia similibus formula, this adynaton expresses individual taste and personality. Indeed, greater originality than other standard curses is a feature of the Mainz tablets. ${ }^{35}$

Moreover, this site remarkably testifies to another significant aspect. The evidence undoubtedly suggests that in Mainz the tablets were put on the fire of sacrificial pits during the ritual of deposition. Several tablets have been found only as lumps of molten lead, three are half melted, while in others the target's

32 Blänsdorf 2012a. See Veale 2017, 301-307 on the deposition of offerings at this sanctuary and the relation between the curses and the site.

33 DTM 15, Mainz, I-II CE: Prima Aemilia Narcissi agat, quidquid conabitur, quidquid aget, omnia illi inversum sit. Amentita surgat, amentita suas res agat. Quidquid surget, omnia interversum surgat. Prima Narcissi aga(t): como haec carta nuncquam florescet, sic illa nuncquam quicquam florescat. Text and translation from Blänsdorf 2010a, 170, slightly modified.

34 See Gordon 2013, 269-271, on physical and mental sufferings in Latin curses.

35 See Blänsdorf 2010a, 146-147: "There are no signs of the standardisation that would indicate professional skill as a scribe. It is consistent with this that, apart from some standard formulae of invocation and curse, most of the texts employ personal, indeed idiosyncratic, language and expressions. Moreover, the typical features of learned or professionallycomposed curse tablets, which only begin to appear during the 2nd century, are entirely absent." On individuality in the Mainz tablets as well as in the documents from Bath, see also McKie 2016. 
life liquefying like lead is a prominent simile. ${ }^{36}$ The consequences of this ritual procedure on human health might have been underestimated in the scholarship. To the best of my knowledge, historians of religion and magic have not sufficiently underlined the toxicity of lead, and how this poisonousness may have affected the experience of cursing rituals. ${ }^{37}$

It has been clinically proven that lead is toxic to adults and children. Ingestion, inhalation, and skin contact are the most common ways in which lead enters the body: since it is only slowly expelled via the feces, it accumulates over time. Lead poisoning is also known as plumbism or saturnism, and gout due to lead intoxication is called Saturnine gout, lead being the alchemical metal of the planet Saturn. The nervous system is remarkably affected, and acute as well as chronic exposure causes cognitive deficiencies such as headaches, lethargy, loss of memory, encephalopathy, muscle tremors, impairment of sensorimotor functions, irritability, depression and anxiety, delirium, and hallucinations. In children, lead exposure results in intelligence quotient loss and severe encephalopathy, while in pregnant women it increases the chance of abortions, miscarriages, stillbirths, reduced gestational age and impaired cognitive development of the fetus (see, ex plurimis, Papanikolaou et al. 2005; White et al. 2007; Vorvolakos et al. 2016). No safe blood concentration of lead is known yet (Flora et al. 2012; Vorvolakos et al. 2016). Neurocognitive deficits in adult men and women may occur from blood-lead concentration levels of 11-20 $\mu \mathrm{g} / 100 \mathrm{ml}$ (Gidlow 2015).

In toxicological studies, the paternity of the discovery of lead toxicity is sometimes erroneously attributed to Hippocrates, while the first to recognize the toxic effects of white lead ( $\psi \mu v \dot{\theta} \theta$ เov, lead carbonate, ceruse) seems to have been Nicander of Colophon in the 2nd century BCE. ${ }^{38}$ Pliny mentions the noxious effects of lead, in particular the toxicity of lead fumes. ${ }^{39}$ The use of lead, pewter, and lead

36 See Blänsdorf 2012a, 39. DTM 2 and 32: severally damaged by fire. DTM 10.9-10, 11.10 and

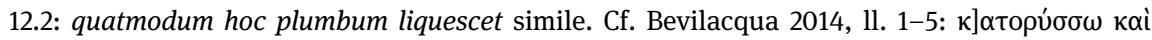

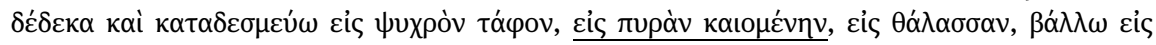



37 But cf. Tomlin 1988, 81, who notes that lead is chemically poisonous.

38 As it is still stated in Papanikolaou et al. 2005, 330, although already Waldron 1973a and 1978 noted that the symptoms of the miner described in Corpus Hippocraticum, De morbis popularibus, VI 25 do not necessarily point to lead colic. Nicander, Alexipharmaca, 74-86 = Gow and Scholfield 1953, 98-99.

39 Pliny, Naturalis Historia, 34.50.167: coquitur ad medicinae usus patinis fictilibus substrato sulpure minuto, lamnis inpositis tenuibus opertisque sulpure et ferro mixtis. cum coquatur, munienda in eo opere foramina spiritus convenit; alioqui plumbi fornacium halitus noxius sentitur. et pestilens est, canibus ocissime, omnium vero metallorum muscis et culicibus, quam ob rem non sunt ea taedia in metallis. On ancient notions of lead toxicity, see Waldron 1973b, 394. 


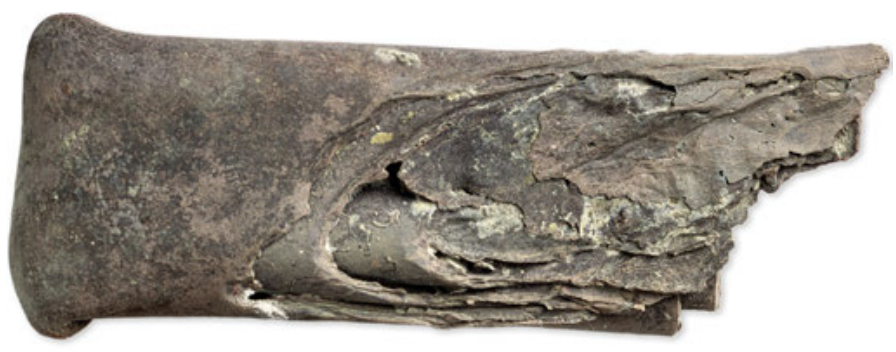

(a)

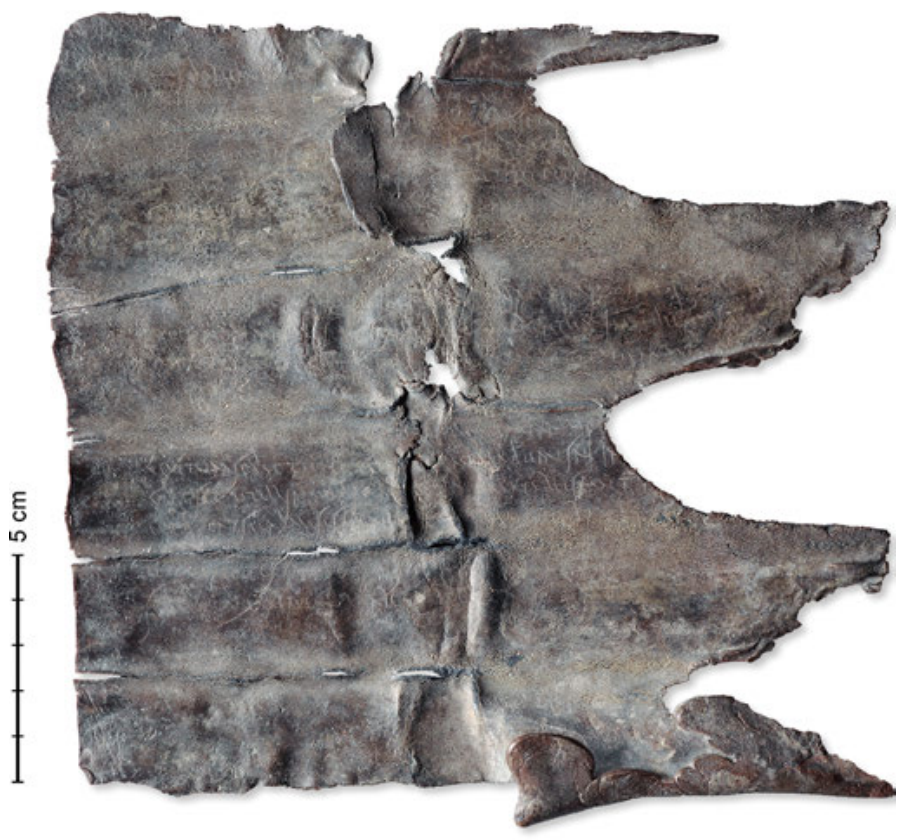

DTM 2 (Inv.-Nr. 182,18) Innenseite

(b)

Fig. 1: DTM 2 rolled (a) and unrolled (b), from Blänsdorf 2012a. Reprint with permission of the GDKE Mainz. 
alloys in Greco-Roman antiquity was extensive and was not restricted to writing materials, ${ }^{40}$ but ranged from cooking and drinking vessels to face powders and white wall paints as ceruse. Especially in the Roman Empire, it was used in the construction of water and sewage systems, and a high (and toxic) proportion of lead was contained in the sapa as well as in the more concentrated defructum, grape must that was boiled down in leaden vessels, reduced, and added to wine and other various recipes as sweetener. ${ }^{41}$ Moreover, since the beginning of the 20th century, historical studies on Occupational Health have traced the clinical effects of lead exposure suffered by miners, metalworkers, and slaves from antiquity. ${ }^{42}$ However, little attention has been devoted to the use of lead in the religious sphere.

Since one of the channels for lead poisoning is dermal exposure, frequent and constant manipulation of lead tablets could have possibly meant long-term skin contact with a toxic material. Absorption could have occurred directly through the skin, or from having handled lead and then touching the eyes, mouth, or nose. Particles could have attached to hair and clothes, and could have been passed on to other people. Considering how tablets were produced - from melting lead or lead alloys, to laying them out on a flat surface, to cutting sheets, to engraving the text, ${ }^{43}$ - the concentration of toxic particles in the workshop of a professional magician could have been high. The fumes from the melting metal and the dust from the cuttings as well as from the engraving with a stylus could have been dangerous sources of contamination on long-term exposure.

40 Besides curses, lead was widely used for writing oracular enquiries (as in the Sanctuary of Zeus at Dodona), commercial transactions and contracts, and personal correspondence; see Ceccarelli 2013, 37 on the qualities of lead, such as light weight and suitability for transmission over long distance, the possibility of folding the lamella for secrecy, and ease for writing complex messages. See Gordon 2015 on lead as material base of curses enhancing their perlocutionary efficacy. See Sánchez Natalías 2018 on how metaphors in curses were interrelated to the material of the writing support.

41 Pliny, Naturalis Historia, 14.27.136: ipsa quoque defruta ac sapa $<s>$, cum sit caelum sine luna, hoc est in sideris eius coitu, neque alio die coqui iubent, praeterea plumbeis vasis, non aereis, nucibusque iuglandibus additis; eas enim fumum excipere. On lead poisoning in antiquity, with a critique of Nriagu 1983's theory that lead intoxication contributed to the fall of the Roman Empire, see, ex plurimis, Waldron 1973b; Prioreschi 1998, 659-661; Warren 2000, 18-21; Dalvi and Pillinger 2013.

42 See Riva et al. 2011 and 2012. See also Retief and Cilliers 2005, 155-156: the sources of pollution considered are (1) water supplies; (2) paints, medicines, and cosmetics; (3) food and beverages to which sugar of lead was added, or prepared in pewter or lead containers; (4) mines, foundries, and manufacturing industries.

43 See Tomlin 1988, 81-84 and Curbera 2014 on the process of tablet production. 
A certain degree of exposure to lead poisoning can be imagined for the participants to the cursing ritual too, especially in the case of Mainz. The procedure of melting the tablets by fire would have generated an elevated concentration of toxic fumes within a not sufficiently ventilated area. Inhaling these fumes and particles, even if in an acute but non-chronic exposure, might have provoked negative effects on health. Unless one tries to reproduce in a laboratory experiment the melting of a Mainz tablet to measure the emission of lead particles, it is impossible to quantify the level of toxicity of these ritual actions. Without further chemical and pharmacological data, we cannot precisely determine the immediate symptoms resulting from acute exposure to the fumes of tablets melting on sacrificial pits. However, the fact that lead is a toxic metal should be included in the picture that tries to describe the religious experience of cursers. It is not an unlikely possibility that cursing rituals in Mainz may have resulted in participants feeling unwell, experiencing intoxication, ${ }^{44}$ or manifesting visual misperceptions and altered mental states, especially if they were recurring to curses frequently. Firstly, as noted above, even a low level of lead contamination may damage organs and systems in the human body. Inhalation of small amounts of lead fumes may cause minor symptoms such as chest pain and headache, but also more seriously memory loss, personality changes, and hallucinations, while larger amounts of lead fumes may provoke delirium and seizures (Dikshith 2013, 241-242). Secondly, we should not forget the impact of suggestibility of the context in eliciting out-of-the-ordinary states of mind. ${ }^{45}$ Even if the lead fumes inhaled during the ritual of deposition had a low level of toxicity without immediate poisonous effects, the participants could have developed psychogenic susceptibility to pain and sensory illusions. It is not unrealistic to suppose that the dedicators of the Mainz tablets were attracting to themselves exactly the sufferings and cognitive deficits that were requested for the target victims. At the end of DTM 2, the half-melted tablet in Fig. 1, we find the following phrasing:

44 On intoxication detectable from archeological remains, and its consequences on sensory perception, in the ancient Mediterranean, see Hamilakis 2013, 50. 135.

45 On mystical experiences in relation to the environment, see Andersen et al. 2014, 223-224: "strong expectations induced in suggestive contexts can elicit quite remarkable effects in individuals' sensory experiences. (...) Sensory deprivation therefore obstructs the brain's attempt to monitor the situation for potential prediction errors;" and 239: "a suggestive context combined with sensory deprivation is sufficient to elicit mystical experiences. We find, however, that successful elicitation of mystical experiences particularly depended upon the cultural background of the participants". I owe this reference to Yulia Ustinova. 
...his abilities, his thinking and wits... (...) Just as salt will <melt in water>, (15) so may his limbs and marrow melt, may he be tortured and may he confess that he has committed sacrilege. I solemnly entrust (this) to you, in order that you may fulfil my wishes and I gladly and willingly return my thanks to you, if you make him die a horrible death. ${ }^{46}$

Asking for the deterioration of the health of the person who had defrauded some money, and then putting the lead tablet into fire, and inhaling the fumes, the defigens was possibly damaging his or her own health. Furthermore, the fumes in combination with the spatial configuration - a confined area, could have generated in the agents a sense of confused thoughts and distorted perception. Sensory deprivation caused by darkness and fumes, metaphorically visualizing the destruction of the opponent by fire, the sacred context, and the cultural predisposition of the believers all could have impacted the way in which the participation in the ritual was experienced.

\section{Emotion, space, and mind at the Fountain of Anna Perenna in Rome}

Out-of-the-ordinary ambience, dark lighting, and a special ceremonial setting constituted key elements of another sacred space where cursing rituals took place. It is our third, and last, case study: the sanctuary of Anna Perenna and her nymphs in Rome. Surely not because of the number 9 repeated three times, in the year 1999, two archaeological sites that have recently contributed most significantly to the history of ancient magic were discovered, the Mainz sanctuary above and this one in Rome. Anna Perenna was a goddess of the cyclical return of the year, previously known from Ovid, who dedicates to her a long section in the third book of his Fasti (Ovid, Fasti, 3.523-526). Outside of the city walls of Rome, a natural spring was enclosed in a sacred precinct and consecrated to her and her nymphs. Inside the fountain, the archaeologists have found a great quantity of depositional material that included 26 lead and copper tablets and seven figurines of bone and wax together with 24 lead containers and three made of terracotta, alongside coins, lamps, pottery, and other findings like pine cones and egg shells (see Piranomonte 2002, 2010, 2016). Although this site deserves a more thorough treatment, I will only mention and

46 DTM 2.11, 14-18, Mainz, I-II CE: copia, cogitatum, mentes. (...) et a[d qu]em modum sal in [aqua liques]cet, sic et illi membra m[ed]ullae extabescant. Cr[ucietur] et dicat se admisisse ne[fa]s. D[e]mando tibi rel[igione,] ut me uotis condamnes et ut laetus libens ea tibi referam, si de eo exitum malum feceris. Translation from Blänsdorf 2010a, 181. 
concisely comment on two texts. Moreover, whereas Marina Piranomonte and Jürgen Blänsdorf have presented the tablets on several occasions and in the catalogue of the Museo Nazionale Romano delle Terme di Diocleziano (Friggeri et al. 2012), we still wait for their complete and final edition. The objects of my analysis are two tablets that exemplarily reveal the mentalities and emotions of the ritual agents here active. This first text is a curse against an arbiter whose organs needed for assessing a legal case and formulating a judgment - his eyes - must be pulled out:

The sacred and holy (nymphs), through the infernal gods and the messengers: what I wish and demand from your great virtue: take the eyes and take them completely away, the right or the left one, of Sura, who lately was born from a cursed vulva. I wish and demand from your great virtue it shall happen: take the eyes, the right and the left one, in order that the virtue of Sura the judge may not persist, who was born from a cursed vulva. $^{47}$

While examining the evidence in preparation for the trial, the victim might have seen something disadvantageous for the author (Blänsdorf 2015, 32-36). The distinction between arbiter and iudex after the Republic was practically nonexistent, but the arbiter was initially the magistrate responsible for deciding over details, "requiring a wide power of discretion: for example, the division of an inheritance or the assessment of a sum owing" (Metzger 2015, 283). Subjective discretion seems to have played a decisive role in this case. The curse might have targeted the judicial discretion of Sura and his ability to see things in a certain way. Thanks to the magna virtus of the divine agents, the virtus of Sura in judging could be crushed. A complex pattern of magical signs and drawings complement the text, which was engraved by a confident writer (Blänsdorf 2010b, 221-227). The drawings of snakes, stylized humans, geometrical shapes, and magical signs contributed to setting apart this message delivered to the underworld gods. The malediction of Sura started from his birth, as affirmed twice in the text and possibly in the drawings as well. The human sketch inside the central rhombus can represent the victim as a baby coming out from the womb (Blänsdorf 2015, 33, following E. Gradavohl). The extension of the curse to the victim's mother is more potent and emotionally charged than the usual formula that identifies the victim specifying the mother's name

47 Tablet inv. no. 475567, Rome, IV/V CE: sacras santas a supteris et angilis quod rogo et peto magnam uirtutem uestram: tollatis pertolla\{e\}tis oculus siue dextrum et sinesteru Surae, qui nat(us) maledicta modo ets de uulua. fiat rogo et peto magnam uirtutem uestra $(m)$. dextra blobes sinestera irilesus tollite oculus dextru sinesteru, ne possit durare uirtus arbitri Surae, qui natu(s) est de uulua maledicta. Transl. Blänsdorf 2015, 34. 
(X quem peperit $Y$ ). ${ }^{48}$ It gives to the curse a primordial root of damnation, and it further justifies the destruction of the victim and his faculties.

The second text is written on a copper tablet and is very fragmentary:

That his persons have been donated [...] and the worshipper (or: the little priest) [...] the son and whoever [...] tomorrow we will appeal as well to your goddesses [...] as to our Christ [. . .those who] now are exulting, shall be in fear [. . . I I shall defeat him. . . ${ }^{49}$

Here there is a rare mention of Jesus Christ in a curse tablet, though the inclusion of divinities from other traditions is frequent in Greek and Latin magical texts. ${ }^{50}$ The author of this curse was Christian, while the opponents (the defixi) were believers in Greco-Roman gods. The Christian author possibly decided to attack them using their very own rituals and sacred places, although he deemed himself to be in an even better position, having also Jesus Christ on his side. Blänsdorf underlines that the expression gaudeant, timiant (that is qui gaudeant timeant) confirms the Christian influence, the only equivalent formula being from the Gospel of Luke: 6.25, "Woe to you who laugh now, for you will mourn and weep". 51 However, another parallel might be offered by a Greek curse tablet from Amorgos, in which the author asks Demeter to "punish those who rejoice in our misery". ${ }^{52}$ The casters of these two spells could have found themselves in a comparable situation: the victims were rejoicing to the detriment of the author, who then wished for fearful punishments that could suppress their grins of malicious exultation

48 A closer parallel is Kropp 2008, no. 11.3.1/1, Constantine/Cirta, IV CE: demando tibi, ut acceptum habeas Silvanum quem peperit vulva facta et custodias, "I entrust to you, that you accept as possession Silvanus, who was born from the vulva, his deeds and care." See Jordan 1976, 131 for other examples in which the womb and not a personal name is mentioned.

49 Tablet inv. no. 475563, Rome, IV/V CE: [- - -]conatas suas [.] person[as - - ] ill[- - -] et uaticolo m[.]l[- - ]erio [- - -] filio et quisquis [.]c[.]rm[..] [roga]mus cras deas uest[ra]s [..]et cristum nostr[um - - Qui] gaudent timi[a]nt t[- - -] eu(m) uincam i[- - ]c[- - ][- - ]suc[.]ui [- - -]; transl. Blänsdorf 2015, 25.

50 Blänsdorf 2012b, 32. See also Németh 2016 on the abbreviation of the name of Jesus Christ Nazarenus in six containers from this site, inscribed inside the drawing of a bird-headed demon. Another invocation to Jesus is in SM 61, a cursing prayer on papyrus from Egypt, IV CE. Cf. Gager 1992, no. 119 (Dalmatia, VI CE), a Latin amulet on a lead tablet invoking Jesus (In nom(ine) $d$ (omi)ni Ieso Cri[s]ti denontio tibi, inmondissime spirete tartaruce) that perhaps could have been used in exorcism rituals as well.

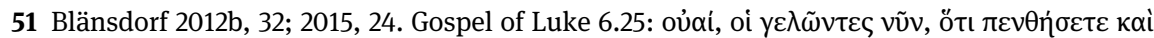

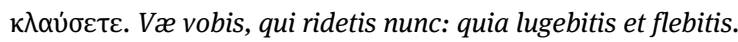

52 IG XII 7, p. 1, B, Amorgos, dated from the Hellenistic to the early Imperial period: (...)

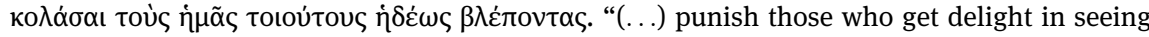
us in such a situation”. See Versnel 1999; Salvo 2012, 257-258. Cf. Eidinow 2016, 226-232. 250-253, for a critical discussion of Schadenfreude as a motivation of binding spells. 
(perhaps on some misfortune of the author). Furthermore, if the opponents are rejoicing today, tomorrow they will be reached by divine punishment from multiple sides, Christian and non-Christian, as the text specifies that the ritual will be taking place the next day (cras) and be, thereupon, immediately effective.

The setting of these cursing practices in Rome is remarkable. Practitioners were approaching an underground cistern outside of city walls, ${ }^{53}$ awakening in secrecy powerful deities from official and unofficial cults. Findings at this site like dolls inside nesting containers allow us to think at the preparatory phase of the ritual as well. Recontextualising for magical aims wax dolls and snakes, everyday objects like containers, lamps, and coins, the agents were starting to adapt and control their rite already at the stage of careful preparation and assembling of objects. During the rite, they were immersed into darkness, damp air, watery visual and aural stimuli, stirring potions in a copper cauldron (caccabus): each element elicited the reception of a plethora of stimuli as counter-intuitive signs, and the complexity of this environment augmented the disposition of the ritual agents towards experiencing a religious mental state.

\section{Concluding remarks}

On a flight from Tel Aviv to Frankfurt in February 2017, I overheard a conversation between a woman and a man. They had first met on the plane, but she was keen on telling him the story of her life. In particular, she told him how her husband had stubbornly refused to concede her a divorce, as required by the halachic law, although the rabbis were in favor of their separation. She decided, then, to visit the Kotel tunnels, the underground remains of the Western Wall from the Second Temple period in Jerusalem. At the next meeting, a rabbi finally managed to persuade her husband, and she obtained the divorce. According to her, the result was not due to the rabbi's persuasive rhetorical ability. It was her visit to the Kotel, and sending a message to God on a piece of paper, that changed everything. This story is worth mentioning because it shows the perceived efficacy of having visited a sacred place for a specific purpose as well as of experiencing a dark, enclosed environment in which actions are set apart. The appeal to the divine for the resolution of a problem is determined by the interaction between space, written materials,

53 On magic in underground retreats and the intention to contact the Underworld, see Ustinova 2009, 240-244; Ogden 2007. On Nymphs, caves, and fountains in late antique magic, see Karivieri 2015, 184-186. 
and emotions of the petitioner and other individuals that need manipulation. In antiquity, the deposition of a curse tablet was an experience in which emotions as well as senses were undergoing a transformation, assuaging the urge for revenge and increasing sensory sensibility.

It is beyond our reach to exactly reconstruct what individuals experienced when invoking divine justice in the Roman Empire. Notwithstanding the examination of some spatial elements and neurobiological features, many questions still remain unanswered. For example, it is hard to prove to what extent the interactions that took place at a sanctuary, facial expressions, blushing due to emotional stress, and body language influenced the interactions among those who were present or nearby, or whether someone who had just performed a cursing ritual could be clearly recognized by members outside of the sacred space. There are indeed challenges inherent to the study of curses as expressions of individual religious experiences, considering the strong formularity of their language and the typical patterns of the genre. Professional magicians could have intently collaborated with their clients, but these could also have engraved the tablets themselves. At any rate, in the act of dedicating the tablets, of putting them on the sacrificial pit, and chanting the spells, the dedicators became the protagonists of the rite. Therefore, individualities can be legitimately tracked down. Furthermore, the limits of formularity can be overcome when archaeological data are available. The characteristics of the space and the objects used in the ceremony allow for untangling the sensory aspects of the ritual experience. If we combine the epigraphical and archaeological data together with neurobiological factors, we may grasp a vague idea of the religious experiences and individual appropriations in Corinth, Mainz, and Rome. In the Sanctuary of Demeter and Kore in Corinth, Room 7 in the Building of the Tablets helped to transform into an "emotional community" the group of people entering it. ${ }^{54}$ Besides the archaeological context, the configuration of the ritual setting and the chosen procedures further help to understand what emotional state could be achieved. The use of a psychoactive substance such as frankincense might have unwound the participants in the ritual. However, other procedures such as the burning of lead tablets in Mainz might have had more perilous effects on mind and body. The lived religious experience could result in an altered state of consciousness, in a sense of distorted perception, and even in an initial intoxication, given the high poisonousness of melted lead. Putting the dedication on fire must have been especially potent in terms of

54 On the concept of "emotional communities" in antiquity, see Chaniotis 2012. 
visual and olfactory stimuli, rendering the ceremony more memorable and charging it with empowering efficacy. Sensory deprivation in a confined and damp space, secrecy, the invocation of deities from more than one system of cult, and out-of-the-ordinary objects impacted the perceptual and cognitive abilities of the devotees of Anna Perenna in Rome.

The scent of frankincense, melted lead, and possibly the altered gazes hint at how behavioral and bodily components made cursing an ever changing and adaptable performance. Depositing a curse created a multi-sensory experience in which both mind and body were affected.

\section{Bibliography}

Andersen, Marc; Schjoedt, Uffe; Nielbo, Kristoffer; Sørensen, Jesper 2014. 'Mystical Experience in the Lab', Method \& Theory in the Study of Religion 26. 217-245.

Bevilacqua, Gabriella 2014. 'Athletai e Palaistai in una defixio greca di Roma', ZPE 188. 215-229.

Blänsdorf, Jürgen 2010a. 'The Defixiones from the Sanctuary of Isis and Mater Magna in Mainz.' In Magical Practice in the Latin West, ed. Richard L. Gordon, Francisco Marco Simón. Leiden. 141-189.

Blänsdorf, Jürgen 2010b. 'The Texts from the Fons Annae Perennae.' In Magical Practice in the Latin West, ed. Richard L. Gordon, Francisco Marco Simón. Leiden. 215-244.

Blänsdorf, Jürgen 2012a. Die Defixionum tabellae des Mainzer Isis- und Mater MagnaHeiligtums. Mainz.

Blänsdorf, Jürgen 2012b. 'La tecnica e l'arte della scrittura su piombo e rame: Le iscrizioni magiche della Fontana di Anna Perenna (Roma) e la tipologia dei caratteri tardo-antichi', Sylloge Epigraphica Barcinonensis (SEBarc) 10. 17-39.

Blänsdorf, Jürgen 2015. 'Gods and Demons in Texts: Figures and Symbols of the Defixion Inscriptions of the Nymphaeum of Anna Perenna at Rome.' In Ancient Magic and the Supernatural in the Modern Visual and Performing Arts, ed. Filippo Carlà, Irene Berti. London/New York. 19-37.

Bookidis, Nancy; Stroud, Ronald S. 1997. Corinth XVIII.3. The Sanctuary of Demeter and Kore: Topography and Architecture. Princeton.

Ceccarelli, Paola 2013. Ancient Greek Letter Writing: A Cultural History (600 BC-150 BC). Oxford. Chaniotis, Angelos 2009. 'Ritual Performances of Divine Justice: The Epigraphy of Confession, Atonement, and Exaltation in Roman Asia Minor.' In From Hellenism to Islam: Cultural and Linguistic Change in the Roman Near East, ed. Hannah M. Cotton et al. Cambridge. 115-153.

Chaniotis, Angelos 2012. 'Moving Stones: The Study of Emotions in Greek Inscriptions.' In Unveiling Emotions: Sources and Methods for the Study of Emotions in the Greek World, ed. Angelos Chaniotis. Stuttgart. 91-129.

Curbera, Jaime 2014. 'From the Magician's Workshop: Notes on the Materiality of Greek Curse Tablets.' In The Materiality of Magic, ed. Dieter Boschung, Jan Bremmer. Paderborn. 97-122.

Curbera, Jaime 2016. 'Five Curse Tablets from the Athenian Kerameikos', ZPE 199. 109-118. 
Dalvi, Sam R.; Pillinger, Michael H. 2013. 'Saturnine Gout, Redux: A Review', The American Journal of Medicine 126. 450.e1-450.e8.

Deleuze, Gilles; Guattari, Felix 1987. A Thousand Plateaus. Minneapolis. French original: Paris 1980.

Dikshith, T.S.S. 2013. Hazardous Chemicals: Safety Management and Global Regulations. Boca Raton.

Dufault, Olivier 2017. 'Who Wrote Greek Curse Tablets?' In Prophets and Profits: Ancient Divination and Its Reception, ed. Richard Evans. London. 45-63.

Eberhard, Johann A. 1910. Synonymisches Handwörterbuch der deutschen Sprache (17th edition.). Leipzig.

Eidinow, Esther 2016. Envy, Poison, and Death: Women on Trial in Ancient Athens. Oxford.

Flora, Gagan et al. 2012. 'Toxicity of Lead: A Review with Recent Updates', Interdiscip Toxicol 5. 47-58.

Friggeri, Rosanna; Granino Cecere, Maria Grazia; Gregori, Gian Luca (eds) 2012. Terme di Diocleziano: la collezione epigrafica. Milan.

Gager, John G. 1992. Curse Tablets and Binding Spells from the Ancient World. New York/ Oxford.

Gidlow, David A. 2015. 'Lead Toxicity', Occupational Medicine 65. 348-356.

Gordon, Richard L. 2013. 'Gods, Guilt and Suffering: Psychological Aspects of Cursing in the North-Western Provinces of the Roman Empire', Acta Classica Universitatis Scientiarum Debreceniensis 49. 255-281.

Gordon, Richard L. 2015. 'Showing the Gods the Way: Curse-Tablets as Deictic Persuasion', Religion in the Roman Empire 1.148-180.

Gow, Andrew S.F.; Scholfield, Alwyn F. 1953. Nicander: The Poems and Poetical Fragments. Cambridge.

Hamilakis, Yannis 2013. Archaeology and the Senses: Human Experience, Memory and Affect. Cambridge.

Jordan, David 1976. 'CIL VIII 19525 (B).2 QPVVLVA = Q(VEM) P(EPERIT) VVLVA', Philologus 120. 127-132.

Karivieri, Arja 2015. 'Tradition and Renewal: The Archaeology of Magic and Theurgy in Athens and Rome in Late Antiquity.' In Tradition: Transmission of Culture in the Ancient World, ed. Jane Fejfer, Mette Moltesen, Annette Rathje. Copenhagen. 181-194.

Kiernan, Philip 2004. 'Did Curse Tablets Work?' In TRAC 2003: Proceedings of the Thirteenth Annual Theoretical Roman Archaeology Conference, ed. Ben Croxford et al. Oxford. 123-134.

Kropp, Amina 2008. Defixiones: Ein aktuelles corpus lateinischer Fluchtafeln: dfx. Speyer.

Marconi, Clemente 2007. Temple Decoration and Cultural Identity in the Archaic Greek World: The Metopes of Selinus. Cambridge.

Masséglia, Jane 2012. 'Emotions and Archaeological Sources: A Methodological Introduction.' In Unveiling Emotions: Sources and Methods for the Study of Emotions in the Greek World, ed. Angelos Chaniotis. Stuttgart. 131-150.

Massumi, Brian 1987. 'Notes on the Translation and Acknowledgements.' In A Thousand Plateaus, ed. Gilles Deleuze, Felix Guattari. Minneapolis. xvii-xx.

Mastrocinque, Attilio 2007. 'Late Antique Lamps with Defixiones', Greek, Roman and Byzantine Studies 47. 87-99. 
McKie, Stuart 2016. 'Distraught, Drained, Devoured, or Damned? The Importance of Individual Creativity in Roman Cursing.' In TRAC 2015: Proceedings of the 25th Annual Theoretical Roman Archaeology Conference 2015, ed. Matthew Mandich et al. Oxford. 15-27.

Metzger, Ernest 2015. 'Litigation.' In The Cambridge Companion to Roman Law, ed. David Johnston. Cambridge. 272-298.

Metzler, Dieter 1995. “'Abstandsbetonung”: Zur Entwicklung des Innenraumes griechischer Tempel in der Epoche der frühen Polis', Hephaistos 13. 57-71.

Meyer, Marvin W.; Smith, Richard 1999. Ancient Christian Magic: Coptic Texts of Ritual. Princeton.

Molden, Daniel C. (ed.) 2014. Understanding Priming Effects in Social Psychology. New York/ London.

Moussaieff, Arieh et al. 2008. 'Incensole Acetate, an Incense Component, Elicits Psychoactivity by Activating TRPV3 Channels in the Brain', FASEB Journal 22. 3024-3034.

Németh, György 2016. 'Jesus in Ancient Pagan Magic: the Anna Perenna Drawings.' In The Wisdom of Thoth: Magical Texts in Ancient Mediterranean Civilisations, ed. Grazyna Bąkowska-Czerner et al. Oxford. 43-48.

Nriagu, Jerome 0. 1983. Lead and Lead Poisoning in Antiquity. New York.

Ogden, Daniel 2007. In Search of the Sorcerer's Apprentice: The Traditional Tales of Lucian's Lover of Lies. Swansea.

Papanikolaou, Nikolas C. et al. 2005. 'Lead Toxicity Update: A Brief Review’, MedSciMonit 11. 329-336.

Piranomonte, Marina (ed.) 2002. Il santuario della musica e il bosco sacro di Anna Perenna. Milano.

Piranomonte, Marina 2010. 'Religion and Magic at Rome: The Fountain of Anna Perenna.' In Magical Practice in the Latin West, ed. Richard L. Gordon, Francesco Marco Simón. Leiden. 191-213.

Piranomonte, Marina 2016. 'The Discovery of the Fountain of Anna Perenna and its Influence on the Study of Ancient Magic.' In The Wisdom of Thoth: Magical Texts in Ancient Mediterranean Civilisations, ed. Grazyna Bąkowska-Czerner et al. Oxford. 71-85.

Prioreschi, Plinio 1998. A History of Medicine: Roman Medicine. Omaha, NE.

Retief, Francois; Cilliers, Louise 2005. 'Lead Poisoning in Ancient Rome', Acta Theologica: Supplementum 7. 147-163.

Riva, Michael A. et al. 2011. "WWorkers" Health Conditions in the Greco-Roman World: The Contribution of Non-Medical Sources', Arch Environ Occup Health 66. 54-55.

Riva, Michael A. et al. 2012. 'Lead Poisoning: Historical Aspects of a Paradigmatic “Occupational and Environmental Disease”, Safety Health Work 3. 11-16.

Rüpke, Jörg 2011. Aberglauben oder Individualität: Religiöse Abweichung im römischen Reich. Tübingen.

Salvo, Irene 2012. 'Sweet Revenge: Emotional Factors in “Prayers for Justice”.' In Unveiling Emotions: Sources and Methods for the Study of Emotions in the Greek World, ed. Angelos Chaniotis. Stuttgart. 235-266.

Salvo, Irene 2016. 'Emotions, Persuasion, and Gender in Greek Erotic Curses.' In Emotion and Persuasion in Classical Antiquity, ed. Ed Sanders, Matthew Johncock. Stuttgart. 263-280.

Salvo, Irene 2017. 'Owners of their Own Bodies: Women's Magic and Reproduction in Greek Inscriptions.' In Women's Ritual Competence in the Ancient Mediterranean, ed. Matthew Dillon, Esther Eidinow, Lisa Maurizio. Farnham. 131-148. 
Sánchez Natalías, Celia 2018. 'The Medium Matters: Materiality and Metaphor in Some Latin Curse Tablets.' In Material Approaches to Roman Magic: Occult Objects and Supernatural Substances, ed. Adam Parker, Stuart McKie. Oxford. 9-16.

Sánchez Natalías, Celia (forthcoming) 2019. 'Seth in the Fountain of Anna Perenna? A New Interpretation of the Magical Container 475549.' In Ancient Magic: Then and Now, ed. Attilio Mastrocinque et al. Nordhausen.

Shariff Azim M. et al. 2016. 'Religious Priming: A Meta-Analysis with a Focus on Prosociality', Pers Soc Psychol Rev 20. 27-48.

Simmel, Georg 1992. Soziologie: Untersuchungen über die Formen der Vergesellschaftung. Frankfurt/M.

Stroud, Ronald 2013. Corinth XVIII.6: The Sanctuary of Demeter and Kore: The Inscriptions. Princeton.

Stewart, Charles 2008. 'Magic and Orthodoxy.' In Greek Magic: Ancient, Medieval and Modern, ed. John C.B. Petropoulos. London/New York. 87-94.

Tarlow, Sarah 2012. 'The Archaeology of Emotion and Affect', Annual Review of Anthropology 41. 169-185.

Tomlin, Roger S.O. 1988. 'The Curse Tablets: Roman Inscribed Tablets of Tin and Lead from the Sacred Spring at Bath.' In The Temple of Sulis Minerva at Bath, 2: The Finds from the Sacred Spring, ed. Barry Cunliffe. Oxford. 59-265.

Ustinova, Yulia 2009. Caves and the Ancient Greek Mind: Descending Underground in the Search for Ultimate Truth. Oxford.

Veale, Sarah 2017. 'Defixiones and the Temple Locus: The Power of Place in the Curse Tablets at Mainz', Magic, Ritual, and Witchcraft 12. 279-313.

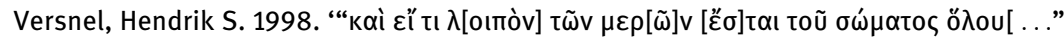
(... and Any Other Part of the Entire Body There May Be ...). An Essay on Anatomical Curses.' In Ansichten griechischer Rituale. Geburtstags-Symposium für Walter Burkert, ed. Fritz Graf. Stuttgart/Leipzig. 217-267.

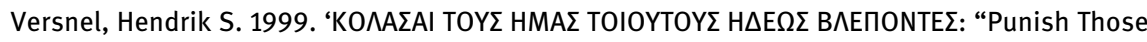
Who Rejoice in Our Misery": On Curse Texts and Schadenfreude.' In The World of Ancient Magic. Papers from the First International Samson Eitrem Seminar at the Norwegian Institute at Athens 4-8 May 1997, ed. David R. Jordan, Hugo Montgomery, Einar Thomassen. Athens. 125-162.

Versnel, Hendrik S. 2002. 'Writing Mortals and Reading Gods: Appeal to the Gods as Dual Strategy in Social Control.' In Demokratie, Recht und soziale Kontrolle im klassischen Athen, ed. David Cohen, Elisabeth Müller-Luckner. Munich. 37-76.

Versnel, Hendrick S. 2010. 'Prayers for Justice, East and West: New Finds and Publications since 1990.' In Magical Practice in the Latin West, ed. Richard L. Gordon, Francisco Marco Simón. Leiden. 275-354.

Vorvolakos, Theofanis et al. 2016. 'There is No Safe Threshold for Lead Exposure: A Literature Review', Psychiatriki 27. 204-214.

Waldron, Tony 1973a. 'Hippocrates and Lead', The Lancet 302. 626.

Waldron, Tony 1973b. 'Lead Poisoning in the Ancient World', Medical History 17. 391-399. Waldron, Tony 1978. 'Did Hippocrates Describe Lead Poisoning?' The Lancet 312. 1315. Warren, Christian 2000. Brush with Death: A Social History of Lead Poisoning. Baltimore, MD. White, Lori D. et al. 2007. 'New and Evolving Concepts in the Neurotoxicology of Lead', Toxicol Appl Pharmacol 15. 1-27. 